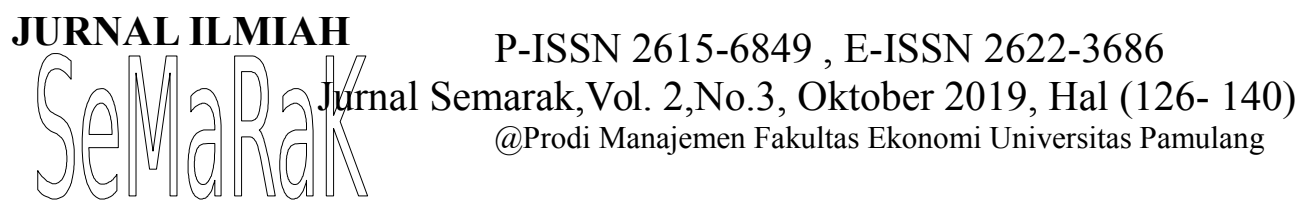

\title{
PENGARUH GAYA KEPEMIMPINAN TERHADAP KINERJA KARYAWAN PADA PT. BIMA BANGUN SENTANA
}

\author{
BACHTIAR ARIFUDIN HUSAIN \\ Fakultas Ekonomi Universitas Pamulang \\ Email : dosen01773@unpam.ac.id
}

\begin{abstract}
ABSTRAK
Penelitian ini bertujuan untuk mengetahui gaya kepemimpinan pada PT. Bima Bangun Sentana, untuk mengetahui kinerja karyawan pada PT. Bima Bangun Sentana, dan untuk mengetahui pengaruh gaya kepemimpinan terhadap kinerja karyawan pada PT. Bima Bangun Sentana.

Penelitian ini menggunakan metode asosiatif kuantitatif dengan instrumen berupa kuesioner.Sumber data pada PT. Bima Bangun Sentana sebanyak 60 orang.Melihat besarnya populasi kurang dari 100, maka menggunakan sampel jenuh.Pengumpulan data dengan kuesioner dan observasi.Uji analisa data yang digunakan adalah uji validitas, uji reliabilitas, uji regresi linier sederhana, uji koefisien korelasi, uji koefisien determinasi, dan uji hipotesis (Uji t).

Hasil penelitian menunjukan bahwa gaya kepemimpinan mendapat respon sangat baik, hal ini dilihat berdasarkan hasil kuesioner menjawab sangat baik sebesar 278 dengan rata-rata skor skala interval 4,48 masuk pada interval $(4,20-5,00)$ atau dengan interpretasi sangat baik dan kinerja karyawan pun sama mendapatkan respon sangat tinggi dilihat dari kuesioner yang menjawab sangat tinggi sebanyak 264 dengan rata-rata skor skala interval 4,51 dengan interpretasi sangat tinggi. Dilihat dari hasil perhitungan regresi linier sederhana di peroleh $\mathrm{Y}=1,897+0,944 \mathrm{X}$, artinya apabila variable gaya kepemimpinan naik 1 satuan maka akan meningkatkan kinerja karyawan sebesar 0,944. Hasil koefisien korelasi diperoleh R Square sebesar 0,724, koefisien determinasi yaitu sebesar 0,524, ini menunjukan bahwa adanya hubungan yang kuat dan pengaruh antara gaya kepemimpinan terhadap kinerja karyawan yaitu sebesar 52,4\% sedangkan sisanya 47,6\% dipengaruhi oleh faktor-faktor lain. Dari perhitungan uji hipotesis (uji $t$ ) dapat diketahui bahwa $t_{\text {hitung }}>t$ tabel $(7,983>2,542)$, yang artinya Ho ditolak dan Ha diterima. Hal ini menunjukan bahwa terdapat pengaruh yang positif dan signifikan antara Gaya Kepemimpinan terhadap Kinerja Karyawan pada PT. Bima Bangun Sentana.
\end{abstract}

\section{Kata Kunci :Gaya Kepemimpinan dan Kinerja Karyawan}




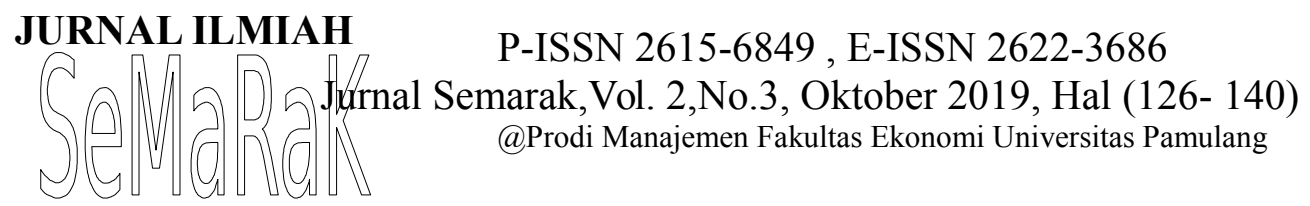

ABSTRACT

This study aims to determine the leadership style at PT. Bima Bangun Sentana, to find out the performance of employees at PT. Bima Bangun Sentana, and to find out the influence of leadership style on employee performance at PT. Bima Bangun Sentana.

This study uses a quantitative associative method with an instrument in the form of a questionnaire. Data sources are primary and secondary data. The population in this study were all employees at PT. Bima Bangun Sentana as many as 60 people. Seeing the population size is less than 100, then using saturated samples.

Collecting data with questionnaires and observations. Data analysis test used is validity test, reliability test, simple linear regression test, correlation coefficient test, test coefficient of determination, and hypothesis test ( $t$ test).

The results showed that the leadership style received a very good response, this was seen based on the results of the questionnaire answering very well at 278 with an average score scale of 4.48 intervals entered at intervals (4.20 - 5.00) or with very good interpretations and the employee's performance was the same as getting a very high response seen from the questionnaire which answered very high as many as 264 with an average score scale interval of 4.51 with very high interpretation.

Judging from the results of simple linear regression calculations obtained $Y=1.897+0.944 X$, meaning that if the leadership style variable rises by 1 unit it will increase employee performance by 0.944 . The results of the correlation coefficient obtained by $R$ Square of 0.724 , the coefficient of determination is equal to 0.524, this shows that there is a strong relationship and the influence of leadership style on employee performance is equal to $52.4 \%$ while the remaining $47.6 \%$ is influenced by other factors. From the calculation of the hypothesis test ( $t$ test) it can be seen that $t$ count $>$ t table (7,983> 2,542), which means that Ho is rejected and Ha is accepted. This shows that there is a positive and significant influence between the Leadership Style on Employee Performance at PT. Bima Bangun Sentana.

\section{Keywords: Leadership Style and Employee Performance}




\section{PENDAHULUAN}

\section{A. LATAR BELAKANG}

Manajemen sumber daya manusia adalah suatu proses yang menangani suatu masalah pada ruang lingkup karyawan, pegawai, buruh, manager dan tenaga kerja lainnya untuk dapat mencapai aktivitas suatu organisasi atau perusahaan demi mencapai tujuan yang telah ditentukan. Menurut Hasibuan (2017:1) Manajemen adalah ilmu dan seni mengatur proses pemanfaatan sumber daya manusia dan sumber-sumber lainnya secara efektif dan efisien untuk mencapai suatu tujuan tertentu. .

Tingkat keberhasilan perusahaan sangat dipengaruhi oleh kinerja karyawannya, dengan demikian perusahaan akan mengupayakan untuk selalu meningkatkan kinerja karyawannya. Salah satu cara untuk memotivasi karyawan agar dapat diberdayakan seefektif dan seefisien mungkin guna meningkatkan produktivitas perusahaan diantaranya dengan penerapan gaya kepemimpinan. Dimana gaya kepemimpinan dapat mempengaruhi perilaku-perilaku karyawan dalam suatu perusahaan.

Menurut Hasibuan (2017:13) mengatakan bahwa "Kepemimpinan adalah gaya seorang pemimpin mempengaruhi bawahannya, agar mau bekerja sama dan bekerja efektif sesuai dengan perintahnya". Kepemimpinan dalam suatu organisasi sangatlah penting, kepemimpinan merupakan salah satu faktor pemicu keberhasilan organisasi tersebut.

Thoha (2013:49) berpendapat "Gaya kepemimpinan merupakan norma perilaku yang digunakan seseorang pada saat orang tersebut mencoba mempengaruhi perilaku orang lain seperti yang ia lihat". Jika seorang pimpinan mampu mengelola perusahaannya dengan kepemimpinan sesuai dengan kebutuhan karyawannya, maka akandapat mendorong dan mempercepatkan tujuan organisasi yang akan di capai.

Gaya kepemimpinan yang dibutuhkan suatu perusahaan untuk meningkatkan kinerja karyawan sehingga mencapai tujuan di tetapkan perusahaan. PT. BimaBangunSentanaadalah perusahaan yang bergerak dalam jasa keamanan (security), didirikan pada 28 September tahun 2002 oleh Bapak Imam Fatoni.Dikarenakan PT. Bima Bangun Sentana bergerak dibidang jasa penyedia keamanan, maka aspek sumber daya manusianya harus sangat diperhatikan, karena itu sangat menentukan tingkat kepuasan dari para konsumen.

Oleh karena itu PT. Bima Bangun Sentana sebagai salah satu perusahaan yang bergerak di bidang penyedia jasa keamanan, dengan tingkat kompetisi yang semakin marak dari perusahaan-perusahaan yang bergerak dibidang yang sama perlu meningkatkan kinerja karyawan mereka.

Melalui proses motivasi dan arahan yang diupayakan melalui penerapan gaya kepemimpinan yang cocok kepada para karyawannya dimana dengan penerapan gaya kepemimpinan yang cocok dari atasanya, diharapkan mampu meningkatkan kinerja para karyawan yang berpengaruh langsung terhadap peningkatan kinerja dan produktivitas dari perusahaan secara keseluruhan yang dapat menjadi nilai tambah sendiri bagi PT. Bima Bangun Sentana dengan perusahaan lain yang bergerak dibidang yang serupa.

Pengertian Kinerja karyawan menurut Widodo (2015:131) adalah prestasi kerja sesungguhnya yang didapat oleh individu yaitu hasil kerja secara kualitas dan kuantitas yang telah di raih oleh seorang pegawai dalam mengerjakan tugasnya sesuai tanggung jawab yang telah diberikan.Menurut Mangkunegara (2015:67) pengertian kinerja karyawan adalah hasil kerja secara kualitas dan kuantitas yang 


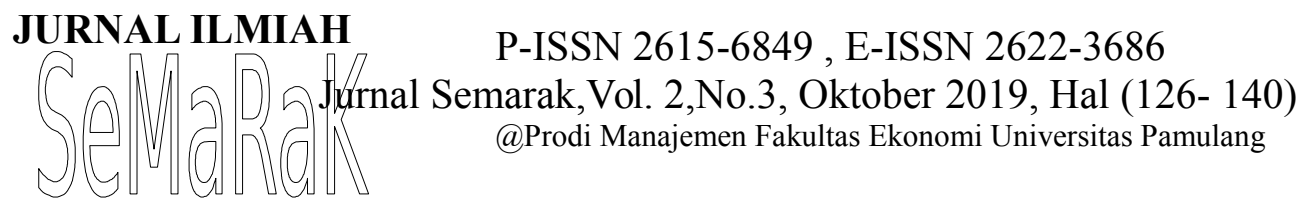

dicapai oleh seorang pegawai dalam melaksanakan tugasnya sesuai dengan tanggung jawab yang diberikan kepadanya.

Faktor lain yang menyebabkan menurunnya kinerja karyawan adalah lingkungan kerja karyawannya yang kurang mendukung, kurangnya fasilitas yang kurang memadai. Beberapa karyawan juga menyebutkan menurunnya kinerja karyawan karena minimnya penghargaan yang diberikan atas prestasi kerja yang dicapai, sehingga karyawan enggan untuk melakukan prestasi yang lebih baik lagi, juga karena beban kerja yang cukup besar.

Berdasarkan beberapa faktor yang dapat mempengaruhi kinerja karyawan yang telah penulis paparkan di atas, maka penulis melakukan

penelitianberjudul"PENGARUH GAYA KEPEMIMPINAN TERHADAP KINERJA KARYAWAN PADA PT. BIMA BANGUN SENTANA".

\section{B. Identifikasi Masalah}

Berdasarkan pada uraian latar belakang masalah di atas, maka penulis dapat mengindentifikasi masalah sebagai berikut :

1. Pemimpin masih kurang mampu dalam memberi pengarahan, dan motivasi untuk disiplin.

2. Gaya kepemimpinan yang diterapkan tidak efektif.

3. Kinerja karyawan kurang maksimal.

4. Karyawan kurang mendapat apresiasi dalam bekerja sehingga prestasi menjadi kurang baik.

\section{Perumusan Masalah}

Dalam penelitian ini rumusan masalahnya adalah :

1. Bagaimana gaya kepemimpinan pada PT. Bima Bangun Sentana?

2. Bagaimana kinerja karyawan pada PT. Bima Bangun Sentana?

3. Bagaimana pengaruh gaya kepemimpinan terhadap kinerja karyawan PT. Bima Bangun Sentana?

\section{Tujuan Penelitian}

Berdasarkan latar belakang dan rumusan masalah yang ada, maka penelitian ini dilakukan dengan tujuan :

1. Untuk mengetahui gaya kepemimpinan pada PT. Bima Bangun Sentana.

2. Untuk mengetahui kinerja karyawan pada PT. Bima Bangun Sentana.

3. Untuk mengetahui pengaruh gaya kepemimpinan terhadap kinerja karyawan pada PT. Bima Bangun Sentana.

\section{TINJAUAN PUSTAKA}

\section{A. Manajemen Sumber Daya Manusia}

Manajemen sumber daya manusia adalah bagian dari manajemen.Oleh karena itu, teori-teori manajemen umum menjadi dasar pembahasannya.Manajemen sumber daya manusia lebih memfokuskan pembahasannya mengenai peraturan peranan manusia dalam mewujudkan 


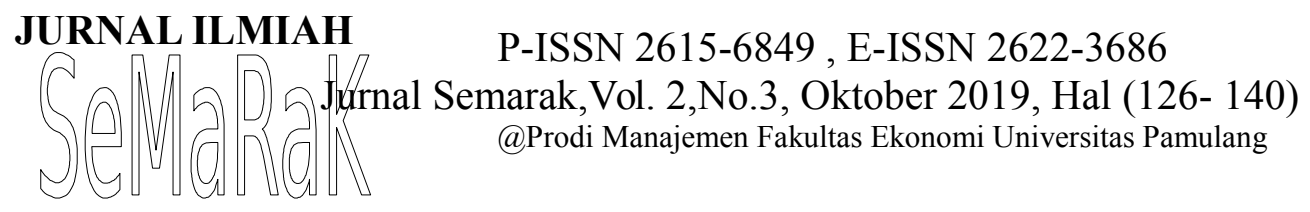

tujuan yang optimal.Sumber daya manusia merupakan faktor yang sangat penting di dalam suatu perusahaan.Karena pentingnya faktor ini maka diperlukan suatu peraturan yang sangat baik. Dari sinilah muncul apa itu yang disebut dengan Manajemen Sumber Daya Manusia.

\section{B. Gaya Kepemimpinan}

Gaya kepemimpinan merupakan pola menyeluruh dari tindakan seorang pemimpin baik yang tampak maupun yang tidak tampak oleh bawahannya.Gaya kepemimpinan menggambarkan dari falsafah yang konsisten, keterampilan, sifat dan sikap yang mendasari perilaku seseorang. Dalam menyukseskan kepemimpinan yang akan diterapkan kepada pegawainya.

Dalam suatu organisasi, faktor kepemimpinan memegang peranan yang sangat penting karena pemimpin itulah yang akan menggerakkan organisasi dalam mencapai tujuan dan tugas sekaligus.merupakan tugas yang tidak. Bawahan dipengaruhi sedemikian rupa sehingga bisa memberikan pengabdian dan partisipasinya kepada organisasi secara efektif dan efisien. Dengan kata lain, bahwa sukses tidaknya usaha pencapaian tujuan organisasi ditentukan oleh kualitas kepemimpinan.

\section{Kinerja Karyawan}

Dalam interaksi sehari-hari antara atasan dan bawahan sering

muncul berbagai asumsi dan harapan lain. Ketika atasan dan bawahan membentuk serangkaian asumsi dan harapan mereka sendiri yang sering agak berbeda, maka perbedaan ini yang akhirnya berpengaruh pada tingkat kinerja.Pada dasarnya kinerja suatu organisasi merupakan akumulasi dari kinerja individu anggota yang bersangkutan.Oleh karena itu peran dan arti pentingnya evaluasi kinerja pegawai sangat penting, baik bagi individu, kelompok, unit kerja, bahkan bagi organisasi itu sendiri.

\section{METODOLOGI PENELITIAN}

\section{Metode Penentuan Sampel}

\section{Populasi}

Populasi penelitian merupakan sekumpulan objek yang ditentukan melalui suatu kriteria tertentu yang akan dikategorikan ke dalam objek tersebut bisa termasuk orang, dokumen atau catatan yang dipandang sebagai objek penelitian. Menurut Sugiyono (2014:119) mendefinisikan"Populasi adalah jumlah wilayah generalisasi yang terdiri atas obyek atau subyek yang mempunyai kualitas dan karakteristik yang ditetapkan oleh peneliti dan kemudian ditarik kesimpulannya".
Sedangkan menurut Arikunto (2013: 173) populasi adalah keseluruhan dari subjek penelitian. Jadi yang dimaksud populasi adalah individu yang memiliki sifat yang sama walaupun prosentase kesamaan 


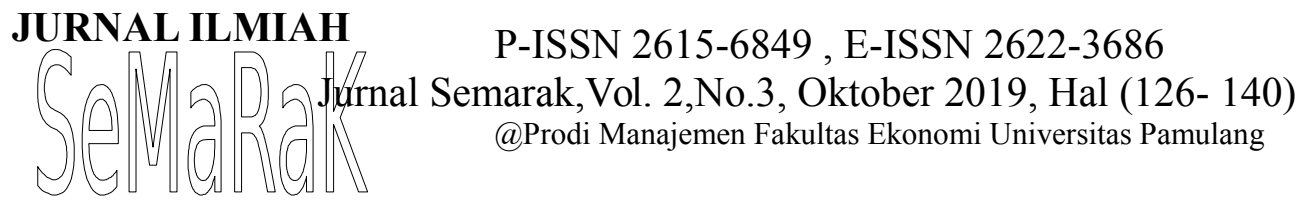

itu sedikit, atau dengan kata lain seluruh individu yang akan dijadikan sebagai obyek penelitian.Populasi merupakan keseluruhan (universum) dari obyek penelitian yang dapat berupa manusia, hewan, tumbuhtumbuhan, udara, gejala, nilai, peristiwa, sikap hidup, dan sebagainya, sehingga obyek-obyek ini dapat menjadi sumber data penelitian. Bungin (2013:101).

\section{Sampel}

Menurut (2014:120)berpendapat Sugiyono "Sampel adalah jumlah dan karakteristik yang dimiliki oleh populasi tersebut". Hasil sampel tersebut didapat menggunakan teknik sampling jenuh.Sampling jenuh adalah teknik penentuan sampel bila semua anggota populasi digunakan sebagai sampel, Sugiyono (2014:189). Sehingga sampel yang digunakan adalah 60 orang Responden

\section{Pengujian Instrumen Penelitian dan Data Penelitian}

\section{Pengujian Instrumen Penelitian}

\section{a. Uji Validitas}

Uji validitas digunakan untuk menguji tingkat kevalidan kuesioner.MenurutSugiyono

(2016: 121) hasil penelitian yang valid apabila terdapat kesamaan antara data yang terkumpul dengan data yang terjadi pada suatu objek yang di teliti, instrumen yang valid berarti alat ukur yang digunakan untuk mendapatkan data (mengukur) itu valid.Valid berarti instrument tersebut dapat digunakan untuk mengukur apa yang seharusnya diukur. Instrumen yang valid berarti alat ukur yang digunakan untuk mendapatkan data (mengukur) itu valid. Untuk menguji setiap instrumen rumus yang dipakai adalah person product moment sebagai berikut :

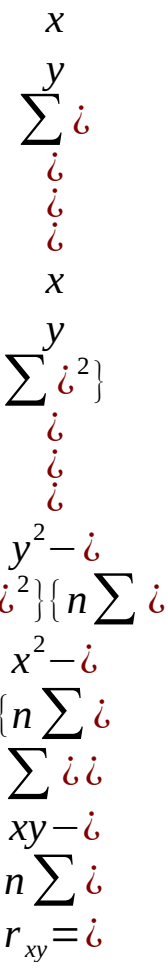

Keterangan:

$\mathrm{r} \quad=$ koefisien korelasi

$\mathrm{n} \quad=$ jumlah responden

$\sum \mathrm{x}=$ jumlah skor dalam distribusi $\mathrm{X}$

$\sum \mathrm{y}=$ jumlah skor dalam distribusi $\mathrm{Y}$

$\sum \mathrm{x}^{2}=$ jumlah kuadrat masingmasing skor $\mathrm{X}$

$\sum \mathrm{y}^{2}=$ jumlah kuadrat masingmasing skor $\mathrm{Y}$

Kriteria kelayakan adalah sebagai berikut:

1) Apabila hasil nilai $r_{\text {hitung }}$ lebih besar dari nilai $r_{\text {tabel, }}$,instrumen 


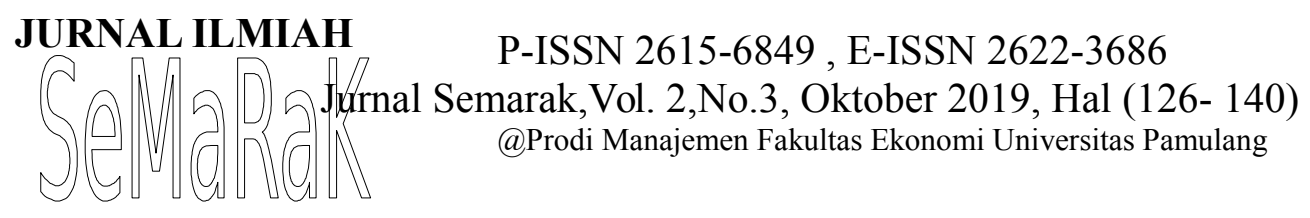

kuesioner dinyatakan valid ( $r_{\text {hitung }}>r_{\text {tabel}}$, valid)

2) Apabila nilai $r_{\text {hitung }}$ lebih kecil dari nilai $r_{\text {tabel }}$, maka instrumen kuesioner dinyatakan tidak valid ( $r_{\text {hitung }}<r_{\text {tabel, }}$, tidak valid).

\section{- Uji Reliabilitas}

Uji reliabilitas digunakan untuk menetapkan apakah instrumen dapat digunakan lebih dari satu kali, paling tidak oleh responden yang sama akan menghasilkan data yang konsisten. Menurut Arikunto (2012:221) reliabiltas adalah "Sesuatu instrument cukup dapat dipercaya untuk digunakan sebagai alat pengumpul data kerena instrument tersebut sudah baik". Cara yang dapat digunakan untuk menguji reliabilitas kuesioner yaitu dengan menggunakan rumus Cronbach Alpha (Sugiyono 2015:365),

$$
\begin{aligned}
& \mathrm{r}=\left[\frac{k}{(k-1)}\right]\left[1-\frac{\sum s i^{2}}{s t}\right] \\
& \mathrm{Si}=\sum_{\substack{\dot{i} \\
\dot{i}^{2}}}^{\substack{\dot{i} \\
x i^{2}-\dot{i}}} \sum_{\dot{i}} \dot{i}
\end{aligned}
$$

$$
\mathrm{St}=\begin{gathered}
\sum_{\dot{i}}^{x i} \dot{i}^{2} \\
\dot{i} \\
\dot{i} \\
\dot{i} \\
-\dot{i} i \\
2 \square^{i} \\
\sum_{i}^{i^{\circ}} i
\end{gathered}
$$

Keterangan :

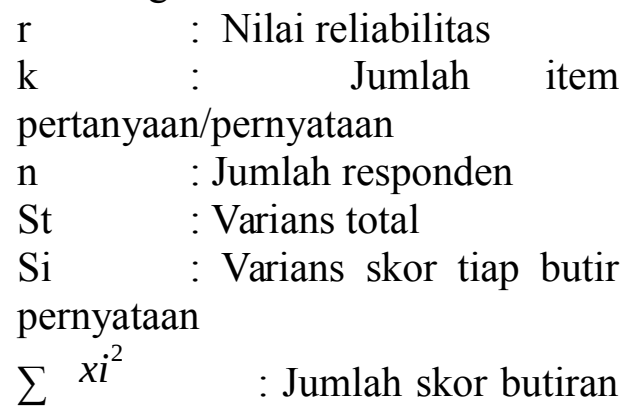

pernyataan

$\sum s i^{2} \quad$ : Jumlah varians butir

$\sum x t^{2}:$ Jumlah skor seluruh pernyataan

Dengan ketentuan uji reliabilitas sebagai berikut, yaitu:

a. Apabila $r_{\text {hitung }}>r_{\text {tabel }}$ (pada taraf signifikan 5\%) maka dapat dikatakan reliabel

b. Apabila $\quad r_{\text {hitung }}<r_{\text {tabel }}$ ( pada taraf signifikan 5\%) maka dapat dikatakan tidak reliabel.

\section{Analisis Koefisien Korelasi}




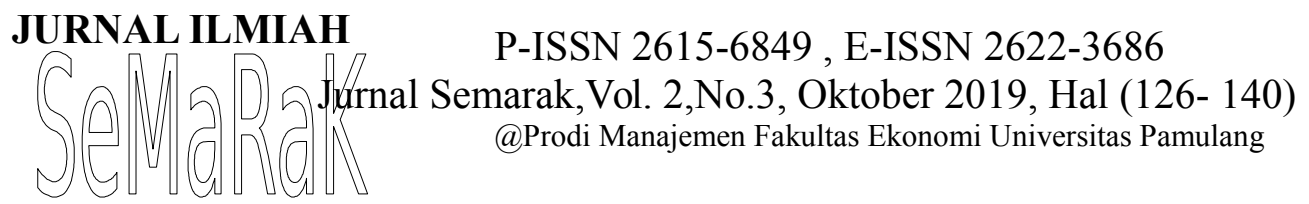

Menurut Sugiyono (2016:183) rumus untuk analisis korelasi product moment adalah:

$X Y$

$$
\begin{gathered}
X \\
\sum_{i}^{Y} i \\
i \sum_{i} X^{2} \\
n \sum Y^{2} \\
\sum i^{2} \\
(i)-i \\
(i)-\left(\sum X^{2}\right) \sqrt{i} \\
\sum i \dot{i} \\
\sum i-i \\
n i \\
r x y=i
\end{gathered}
$$

Keterangan:

$\mathrm{r}=$ Koefisien korelasi

$\mathrm{n}=$ Jumlah sampel

$\mathrm{X} \quad=$ Variabel independen

$\mathrm{Y} \quad=$ Variabel dependen

$\sum \mathrm{X}=$ Jumlah skor tiap butir soal

$\sum \mathrm{Y}=$ Jumlah skor total

$\sum X Y=$ Jumlah hasil skor tiap butir soal dengan skor total

Dengan ketentuan sebagai berikut :

1 Apabila nilai $\mathrm{r}>0$, maka hubungan antara $\mathrm{X}$ dan $\mathrm{Y}$ merupakan hubungan yang positif yaitu semakin besar nilai variabel $\mathrm{X}$ (bebas), maka semakin besar pula pengaruh terhadap nilai variabel Y (terikat), atau sebaliknya semakin kecil variabel
$\mathrm{X}$ (bebas), maka semakin kecil pula variabel Y (terikat).

2 Apabila nilai $\mathrm{r}<0$, maka hubungan antara $\mathrm{X}$ dan $\mathrm{Y}$ merupakan hubungan negatif, yaitu semakin kecil variabel $\mathrm{X}$ (bebas), maka semakin besar nilai variabel Y (terikat), atau semakin besar variabel $\mathrm{X}$ (bebas), maka semakin kecil nilai variabel $\mathrm{Y}$ (terikat).

3 Apabila nilai $\mathrm{r}=0$, maka antara variabel $\mathrm{X}$ dan variabel $\mathrm{Y}$ tidak ada hubungan sama sekali. Variabel X tidak ada kontribusi sama sekali terhadap variabel Y.

4 Apabila $r=1$ terdapat hubungan positif yang sempurna antara variabel $\mathrm{X}$ dengan variabel $\mathrm{Y}$

5 Apabila nilai $\mathrm{r}=-1$, maka telah terjadi hubungan negatif yang sempurna antara variabel $\mathrm{X}$ (bebas) dengan variabel $\mathrm{Y}$ (terikat).

\section{Analisis Koefisien Determinasi (KD)}

Analisis ini bertujuan untuk mengetahui seberapa besar pengaruh variabel $(x)$ dan variabel (y).menunjukkan besaran tingkat kekuatan hubungan antara dua variabel atau lebih dalam bentuk persen (menunjukkan seberapa besar persentase variabel $(\mathrm{X})$ dapat memberikan kontribusi terhadap variabel (Y).

\section{Pengujian Hipotesis}

\section{a. Uji Signifikasi / Uji t}

Untuk dapat mengetahui pengaruh yang signifikasi antara variabel bebas $(x)$ dengan 


$$
\begin{aligned}
& \text { JURNAL ILMIAH P-ISSN 2615-68 } \\
& \text { variabel terikat }(y) \text { maka perlu } \\
& \text { dilakukan uji signifikasi korelasi } \\
& \text { dengan mengunakan uji- } t \\
& t=\frac{r \sqrt{n-2}}{\sqrt{1-r^{2}}}
\end{aligned}
$$$$
\text { P-ISSN 2615-6849, E-ISSN 2622-3686 }
$$

Keterangan:

$t=i$ Nilai $\mathrm{t}$ hitung yang selanjutnya dibandingkan dengan nilai $t_{\text {tabel }}$

$$
\begin{array}{lll}
r=i & \text { Nilai koefisien korelasi } \\
n=i & \text { Jumlah } & \text { sampel }
\end{array}
$$

(responden)

Tingkat signifikasi

$\mathrm{a}=5 \%$

$\mathrm{t}_{\text {tabel }}(\mathrm{df}=\mathrm{n}-2)$

Kaidah Pengujian:

a Jika $t_{\text {hitung }}>$ dari $t_{\text {tabel, }}$ maka signifikan (Ho ditolak, Ha di terima)

b Jika $t_{\text {hitung }}<$ dari $t_{\text {tabel, }}$ maka signifikasi (Ho diterima, $\mathrm{Ha}$ di tolak)

\section{G. Operasional Variabel Penelitian}

Menurut Hatch dan Farhady (1981) dalam buku Sugiono (2015:38) menyampaikan secara teoritis variabel dapat didefinisikan sebagai atribut seseorang atau obyek, yang mempunyai variasi antara satu orang dengan yang lainnya atau satu obyek dengan obyek lainnya. Sedangkan Kerlinger (1973) dalam buku Sugiono (2015:39) menyatakan bahwa variabel adalah konstruk (constructs) atau sifat yang akan dipelajari.
1.

Variabel

Independen(Variabel Bebas)

Menurut Sugiyono (2016:39) variabel bebas diartikan sebagai variable dapat mempengaruhi perubahannya variabel dependen (terikat).variabel bebasnya adalah Gaya Kepemimpinan.

2.

Variabel

Dependen (Variabel Terikat)

Menurut Sugiyono (2016:39) variabel terikat merupakan variabel yang dipengaruhi karena adanya variabel bebas.Di dalam penelitian ini, yang menjadi variable terikatnya adalah Kinerja Karyawan.

\section{HASIL DAN PEMBAHASAN}

\section{Hasil Pengolahan Data}

a. Uji Validitas

(Uji Instrumen)

Uji validitas ini digunakan untuk menguji pertanyaan maupunpernyataan setiap kuesioner valid atau tidak, Selanjutnya untuk mengolah uji validitas, peneliti menggunakan program SPSS versi 22 dengan kriteria sebagai berikut:

a. Jika nilai $\mathrm{r}_{\text {hitung }}$ lebih besar dari $r_{\text {tabel }}\left(\mathrm{r}_{\text {hitung }}>r_{\text {tabel }}\right)$ nilai $\mathrm{r}$ positif, maka valid.

b. Jika nilai $\mathrm{r}_{\text {hitung }}$ lebih kecil dari $r_{\text {tabel }}\left(\mathrm{r}_{\text {hitung }}>r_{\text {tabel }}\right)$ dan nilai $r$ negatif, maka butir yang dikatakan tidak valid.

Adapun nilai $\mathrm{r}_{\text {tabel }}$ untuk 60 ssmpel taraf signifikansi $\alpha=$ 
$0,05 \quad(5 \%)$ dengan tingkat pengujiannya adalah $55 \%$.

Pengujian Validitas variabel Kinerja Karyawan (Y)

\section{b. Uji Reliabilitas}

Suatu pertanyaandapat dikatakan reliabel atau handal jika jawaban responden terhadap pernyataan adalah konsisten atau stabil dari waktu ke waktu (Sugiyono, 2014:183).

Adapun nilai $\mathrm{r}_{\text {tabel }}$ untuk 60 responden dengan taraf signifikansi $\alpha=0,05$ (5\%) artinya tingkat kepercayaan pengujiannya adalah 55\%. Hasil uji reliabilitas penilitian ini menggunakan program SPSS Versi 22, hasilnya sebagai berikut :

\section{Tabel 6}

\section{Hasil Uji Reliabilitas Data}

\begin{tabular}{|c|l|c|c}
\hline No & \multicolumn{1}{|c|}{ Variabel } & r hitung & \\
\hline 1 & $\begin{array}{l}\text { Gaya } \\
\text { Kepemimpinan } \\
(\mathrm{X})\end{array}$ & 0,621 & \\
\hline 2 & $\begin{array}{l}\text { Kinerja } \\
\text { Karyawan (Y) }\end{array}$ & 0,738 & \\
\hline
\end{tabular}

Sumber : Data Primer diolah.

Berdasarkan hasil uji reliabilitas pada tabel, dan dapat diketahui bahwa seluruh variabel yang dinyatakan reliablel, karena $r$ hitung lebih besar dari $\mathrm{r}$ tabel.

\section{Model Summary}

\begin{tabular}{|l|c|r|r|r|}
\hline Model & R & R Square & $\begin{array}{c}\text { Adjusted R } \\
\text { Square }\end{array}$ & $\begin{array}{c}\text { Std. Error of } \\
\text { the Estimate }\end{array}$ \\
\hline 1 & $.724^{\mathrm{a}}$ & .524 & .515 & 2.67478 \\
\hline
\end{tabular}

a. Predictors: (Constant), Gaya Kepemimpinan

\section{Analisis Regresi Linier Sederhana}

Uji regresi sederhana ini dapat dimaksudkan mengetahui seberapa besar pengaruh variabel Xterhadap variabel Y. Dalam penelitian ini adalah Gaya Kepemimpinan (X) dan Kinerja Karyawan (Y).

Berikut ini hasil olahan data regresi dengan SPSS versi 22 yang dapat dilihat pada tabel berikut ini :

Tabel 7

Hasil Pengolahan Regresi Sederhana Variabel Gaya Kepemimpinan (X) dan Kinerja Karyawan (Y)

Sumber : Data Primerdiolah. Berdasarkan hasil perhitungan regresi pada tabel diatas, diperoleh persamaan regresinya $\mathrm{Y}=1,897+0,944 \mathrm{X}$. Dari persamaan di atas maka dapat disimpulkan sebagai berikut:

$1,897=$ Jika Gaya Kepemimpinan $(\mathrm{X})=0$ atau konstan, maka Kinerja Karyawan akan bernilai 1,897.

0,944 = Jika Gaya Kepemimpinan (X) mengalami peningkatan sebesar satu satuan, maka Kinerja Karyawan (Y) akan mengalami peningkatan sebesar 0,944 kali.

. Analisis Koefisien Korelasi (R).

Analisis koefisien korelasi dimaksudkan untuk mengetahui tingkat kekuatan hubungan atau pengaruh antara variabel independen variabel dependen baik secara parsial secara simultan.Adapun hasil analisisnya sebagai berikut:

\section{Tabel 8}

\section{Hasil Analisis Koefisien Korelasi}

Sumber : Data premier diolah

Dari tabel diatas, diperoleh nilai koefisien korelasi sebesar 0,724,maka dapat 


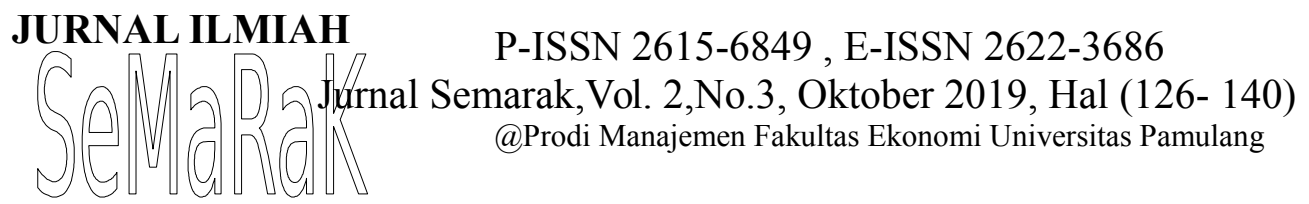

disimpulkan bahwa variabel Gaya Kepemimpinan (X) memiliki tingkat kekuatan hubungan yang kuatterhadap Kinerja Karyawan (Y).

\section{Analisis Koefisien Determinasi}

Koesfisien Determinasi $(\mathrm{Kd})$ dipergunakan untuk mengetahui seberapa besar pengaruh antara variabel Gaya Kepemimpinan terhadap variabel Kinerja Karyawan baik secara parsial maupun simultan.

Adapun cara mengetahui tingkat hubungan tersebut dipergunakan rumus sebagai berikut : $\mathrm{KD}=\mathrm{R}^{2} \times 100 \%$ yang diolah dengan program SPSS versi 22, terlihat pada tabel bawah ini:

Tabel 9

Hasil Koefisien Determinasi Variabel Gaya Kepemimpinan (X)Terhadap Kinerja Karyawan (Y)

terhadap Kinerja Karyawan (Y) dapat dilakukan dengan uji statistik $t$ (uji secara simultan).

Dalam penelitian ini digunakan kriteria signifikansi $\quad 5 \% \quad(0,05)$ dengan membandingkan $t$ hitung dengan $t$ tabel yaitu sebagai berikut :

1) Jika $t_{\text {hitung }}<t_{\text {tabel }}$ : berarti $\mathrm{H}_{0}$ diterima dan $\mathrm{H}_{1}$ ditolak $(\alpha=5 \%)$

2) Jika $t_{\text {hitung }}>t_{\text {tabel }}$ : berarti $\mathrm{H}_{0}$ ditolak dan $\mathrm{H}_{1}$ diterima $(\alpha=5 \%)$

Adapun untuk untuk menentukan besarnya $\mathrm{t}$ tabel dicari dengan menggunakan rumus berikut ini : $t_{\text {tabel }}=\mathrm{t} \alpha . \mathrm{df}$ (Taraf Alpha $\mathrm{x}$ Degree of Freedom)

$$
\alpha=\text { tarif nyata }
$$

Model Summary

\begin{tabular}{c|l|l|r|r|r|}
\multirow{4}{*}{$\begin{array}{c}\text { Sumber : } \\
\text { Data Primer diolah }\end{array}$} & $\begin{array}{l}\text { Mode } \\
1\end{array}$ & \multicolumn{1}{|c|}{$\mathrm{R}$} & $\mathrm{R}$ Square & $\begin{array}{l}\text { Adjusted R } \\
\text { Square }\end{array}$ & $\begin{array}{l}\text { Std. Error of } \\
\text { the Estimate }\end{array}$ \\
\cline { 2 - 6 } & 1 & $.724^{\mathrm{a}}$ & .524 & .515 & 2.67478 \\
\hline
\end{tabular}

a. Predictors: (Constant), Gaya Kepemimpinan

Dari tabel diatas, 5\% diperoleh nilai koefisien determinasi sebesar 0,524 maka dapat disimpulkan bahwa kontribusi pengaruh antara variabel Gaya kepemimpinan (X) terhadap variabel Kinerja Karyawan (Y) sebesar 52,4\% sedangkan hasilny $47,6 \%$ dipengaruhi oleh faktor-faktor lain

6. Pengujian Hipotesis

a. Uji Hipotesis (t hitung)

Untuk pengujian pengaruh antara variabel Gaya Kepemimpinan (X)

df diperoleh $(60-2)=58$

$$
t_{\text {tabel }}=2,542
$$

Adapun rumusan hipotesis dalam penelitian ini adalah Rumusan hipotesisnya adalah :

$\mathrm{H}_{0}: \rho=0 \quad$ Tidak terdapat pengaruh positif dan signifikan antara Gaya Kepemimpinanterhadap

Kinerja Karyawan.

$\mathrm{H}_{1}: \rho \neq 0 \quad$ Terdapat pengaruh positif dan signifikan antara Gaya 


\section{Coefficients $^{\mathrm{a}}$}

\begin{tabular}{|c|c|c|c|c|c|}
\hline \multirow[b]{2}{*}{ Model } & \multicolumn{2}{|c|}{$\begin{array}{c}\text { Unstandard } \\
\text { ized } \\
\text { Coefficient } \\
\text { s }\end{array}$} & $\begin{array}{c}\text { Stan } \\
\text { dard } \\
\text { ized } \\
\text { Coef } \\
\text { ficie } \\
\text { nts }\end{array}$ & & \\
\hline & B & $\begin{array}{l}\text { Std. } \\
\text { Error }\end{array}$ & Beta & $\mathrm{t}$ & Sig. \\
\hline $\begin{array}{c}1 \text { (Cons } \\
\operatorname{tant})\end{array}$ & $\begin{array}{r}1.89 \\
7\end{array}$ & $\begin{array}{r}5.21 \\
7\end{array}$ & & $\begin{array}{r}36 \\
4\end{array}$ & .718 \\
\hline $\begin{array}{l}\text { Gaya } \\
\text { Kepe } \\
\text { mimp } \\
\text { inan }\end{array}$ & .944 & .118 & .724 & $\begin{array}{r}7 . \\
98 \\
3\end{array}$ & .000 \\
\hline
\end{tabular}

a. Dependent Variable: Kinerja Karyawan

Kepemimpinanterhadap

Kinerja Karyawan.

Adapun hasil pengolahan data menggunakan program SPSS

Versi 22, dengan hasil sebagai berikut :

Tabel 10. Hasil Uji t Variabel Gaya Kepemimpinan (X)
Sumber : Data Primer diolah

Dari tabel diatas diperoleh nilai $t$ hitung $>t$ tabel $(7,983>2,542)$, untuk itu $\mathrm{H}_{0}$ ditolak dan $\mathrm{H}_{1}$ diterima, hal ini menunjukkan bahwa terdapat pengaruh yang positif dan signifikan antara Gaya Kepemimpinan terhadap Kinerja Karyawan.

\section{Pembahasan Penelitian} Gaya kepemimpinan merupakan pola menyeluruh dari tindakan seorang pemimpin baik yang tampak maupun yang tidak tampak oleh bawahannya.Gaya kepemimpinan menggambarkan dari falsafah yang konsisten, keterampilan, sifat dan sikap yang mendasari perilaku seseorang. Dalam menyukseskan kepemimpinan dalam organisasi, pemimpin perlu memikirkan dan memperlihatkan gaya kepemimpinan yang akan diterapkan pegawainya.

Gaya Kepemimpinan pada PT. Bima Bangun Sentana sudah sangat baik.Dilihat berdasarkan hasil kuesioner menjawab sangat baik sebesar 278 dengan rata-rata skor skala interval 4,48 masuk pada interval $(4,20-5,00)$ atau dengan interpretasi sangat baik.Namun tetap pemimpin harus memberikan masukan-masukan yang membangun, sebagai acuan kemajuan kerja pada karyawan di perusahaan.

Kinerja Karyawan pada 


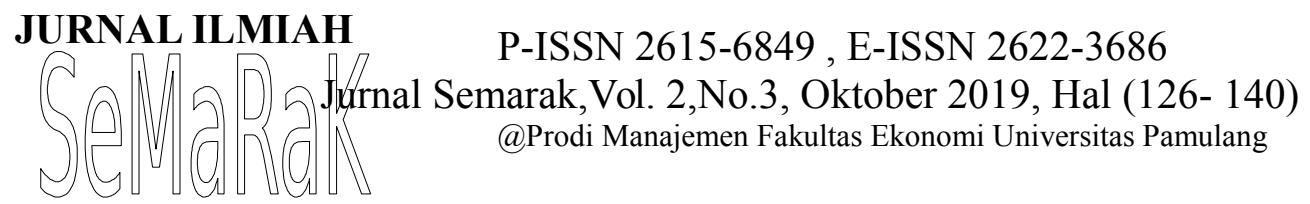

PT. Bima Bangun Sentana juga sudah sangat baik.Dilihat dari kuesioner yang menjawab sangat tinggi sebanyak 264 dengan ratarata skor skala interval 4,51 dengan interpretasi sangat tinggi.Namun harus tetap memperhatikan masalah penilaian kualitas kerja karyawan agar bisa menilai secara baik, juga terkait dengan absensi karyawan perlu juga ditingkatkan lagi.

Berdasarkan hasil penelitian, menunjukkan bahwa Gaya Kepemimpinan dan Kinerja Karyawan berpengaruh positif pada PT. Bima Bangun Sentana dengan persamaan regresi $\mathrm{Y}=1,897+$ 0,944X. Hasil regresi menghasilkan koefisien gaya kepemimpinan sebesar 0,944 bertanda positif dan kinerja karyawan sebesar 1,897. Semakin baik gaya kepemimpinan yang diterapkan, kinerja karyawan yang kurang baik maka gaya kepemimpinan yang diterapkan kurang tepat.

Berdasarkan hasil statistik dapat diketahui bahwa pengaruh Gaya Kepemimpinan (X) terhadap Kinerja Karyawan (Y) adalah 0,524 atau sebesar sebesar $52,4 \%$ sedangkan sisanya $\quad 47,6 \%$ dipengaruhi oleh faktor-faktor lain. Hal ini menunjukkan bahwa Gaya Kepemimpinan yang baik akan meningkatkan Kinerja Karyawan. Koefisien korelasidiperoleh R Square sebesar 0,724, ini menunjukan bahwa adanya hubungan yang kuatantara Gaya Kepemimpinan terhadap Kinerja Karyawan.Dari pengujian hipotesis diperoleh $\mathrm{t}$ hitung $>\mathrm{t}$ tabel atau $(7,983>2,542)$ sehingga $\mathrm{H}_{0}$ ditolak dan $\mathrm{H}_{1}$ diterima artinya terdapat pengaruh yang saling berhubungan.

$$
\text { Hasil penelitian ini }
$$
konsisten dengan hasil penelitian yang dilakukan oleh Agus Jamaludin(Jurnal Bisnis Terapan dan Ekonomi, Vol.3 No. 3 (Maret 2017) 161-169)yang meneliti tentang "Pengaruh Gaya Kepemimpinan Terhadap Kinerja Karyawan pada PT. Kaho Indahcitra Garment Jakarta.". Dalam penelitiannya menunjukkan bahwa terdapat pengaruh yang positif dan signifikan antara Gaya Kepemimpinan terhadap Kinerja Karyawan, dan ini sesuai dengan pendapat Menurut Thoha (2013:49) berpendapat "Gaya kepemimpinan merupakan norma perilaku yang digunakan seseorang pada saat orang tersebut mencoba mempengaruhi perilaku orang lain seperti yang ia lihat".

\section{PENUTUP}

1.

\section{pulan}

Berdasarkan hasil penelitian yang penulis lakukan dan di dukung dengan teori-teori yang dijadikan landasan berpikir dalam permasalahan disertai pemaparan pada pembahasan yang telah dilakukan mengenai gaya kepemimpinan terhadap kinerja karyawan pada PT. Bima Bangun Sentana, maka kesimpulan yang dapat diambil sebagai berikut :

1. Gaya Kepemimpinan pada PT. Bima Bangun Sentana sudah sangat baik. Dilihat 


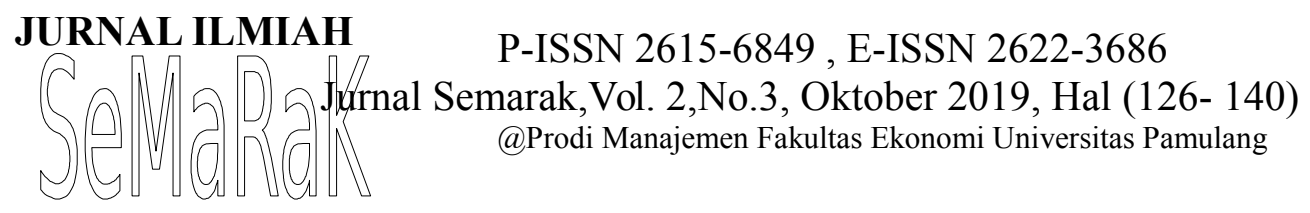

berdasarkan hasil kuesioner menjawab sangat baik sebesar 278 dengan ratarata skor skala interval 4,48 masuk pada interval $(4,20-$ $5,00)$ atau dengan interpretasi sangat baik.Dalam indikator nilai soal nomor 2 dengan pernyataan "Atasan memimpin perusahaan dengan wawasan yang luas untuk diterapkan kepada karyawan diperusahaan".

2. Kinerja Karyawan pada PT. Bima Bangun Sentana juga sudah sangat baik. Dilihat dari kuesioner yang menjawab sangat tinggi sebanyak 264 dengan ratarata skor skala interval 4,51 dengan interpretasi sangat tinggi. Dalam indikator nilai soal nomor 2 dengan pernyataan "Dalam menyelesaikan pekerjaan karyawan selalu bekerja secara maksimal".

3. Dilihat dari hasil perhitungan regresi linier sederhana di peroleh $\mathrm{Y}=1,897+0,944 \mathrm{X}$, artinya apabila variable gaya kepemimpinan naik 1 satuan maka akan meningkatkan kinerja karyawan sebesar 0,944. Hasilkoefisien korelasidiperoleh R Square sebesar 0,724, koefisien determinasi yaitu sebesar 0,524 , ini menunjukan bahwa adanya hubungan yang kuat dan pengaruh antara gaya kepemimpinan terhadap kinerja karyawan yaitu sebesar $52,4 \%$ sedangkan sisanya $47,6 \%$. Dari perhitungan uji hipotesis (uji t) dapat diketahui bahwa $t_{\text {hitung }}>t_{\text {tabel }}(7,983>2,542)$, yang artinya Ho ditolak dan $\mathrm{Ha}$ diterima. Hal ini menunjukan bahwa terdapat pengaruh yang positif dan signifikan antara Gaya Kepemimpinan terhadap Kinerja Karyawan pada PT. Bima Bangun Sentana

2.

Berdasarkan kesimpulan yang telah diuraikan maka penulis mencoba mengemukakan beberapa saran yang kiranya dapat bermanfaat bagi PT. Bima Bangun Sentana.

1. Sebaiknya gaya kepemimpinan di PT. Bima Bangun Sentana yang sudah ada dipertahankan, karena kinerja karyawan pada PT. Bima Bangun Sentana banyak dipengaruhi oleh pimpinan saat ini.

2. Diharapkan seorang pemimpin harus melakukan pengawasan, memberikan masukan atau saran yang membangun, walaupun sudah sangat baik, tapi hal itu perlu dilakukan demi kemajuan perusahaanpada PT. Bima Bangun Sentana.

3. Disiplin dalam kinerja karyawan sudah tinggi, namun harus lebih ditingkatkan terkait absensi karyawan, supaya waktu dapat digunakan secara efisien, serta memberi sikap tegas bagi karyawan yang jarang hadir, agar karyawan dapat memberikan kemajuan pada PT. Bima Bangun Sentana jika kinerja 


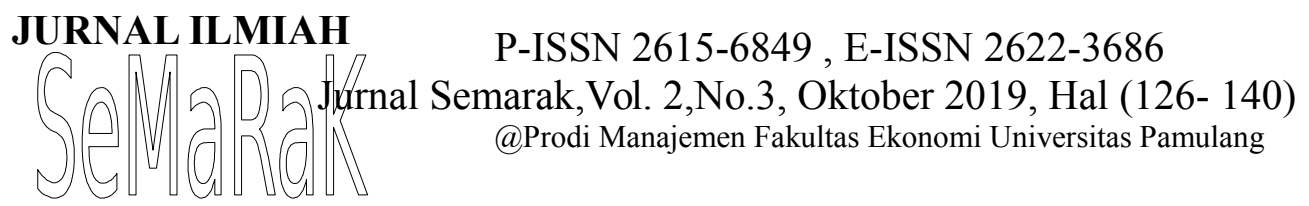

karyawan dapat maksimal.

\section{DAFTAR PUSTAKA}

Amirullah, "Kepemimpinan dan Kerja Sama Tim", Mitra Wacana, Jakarta, 2015.

Mangkunegara, Anwar Prabu "Manajemen Sumber Daya Manusia Perusahaan", Bandung, Remaja Rosdakarya, 2013.

\begin{tabular}{lr} 
& \\
\hline $\begin{array}{l}\text { Sumber Daya } \\
\text { Perusahaan", } \\
\text { Rosdakarya, 2014. }\end{array}$ & Manusia \\
Bandung,
\end{tabular}

\section{, "Manajemen Sumber Daya Manusia Perusahaan", Bandung, Remaja Rosdakarya, 2015.}

Arikunto, Suharsimi, "Prosedur Penelitian Suatu Pendekatan Praktek", Jakarta, PT. Rineka Cipta, 2012. , "Prosedur Penelitian Suatu Pendekatan Praktek", Jakarta, PT. Rineka Cipta, 2013.

Bungin, Burhan, "Metode Penelitian Sosial \& Ekonomi: Format-Format Kuantitatif dan Kualitatif untuk Studi Sosiologi, Kebijakan, Publik, Komunikasi, Manajemen, dan Pemasaran", Jakarta, Edisi Pertama, Kencana Prenada Media Group, 2013.

Widodo, Eko Suparno, "Manajemen Pengembangan Sumber Daya Manusia", Yogyakarta, Pustaka Pelajar, 2015.
Fahmi, Irham, "Manajemen Kinerja Teori dan Aplikasi", Jakarta, Prestasi Pustaka, 2015.

Hasibuan, Malayu S.P., "Manajemen Sumber Daya Manusia", Jakarta, Edisi Revisi, Cetakan Kedelapan Belas, Remaja Rosdakarya, 2017.

"Manajemen

Sumber Daya Manusia". Jakarta, Edisi Revisi, Cetakan Ketujuh Belas, Remaja Rosdakarya, 2013.

Kasmir, "Manajemen Sumber Daya Manusia (Teori dan Praktik), Depok, PT. Rajagrafindo Persada, 2016.

Krisnaldy, K., Pasaribu, V. L. D., \& Senen, S. (2019). PENGARUH BUDAYA ORGANISASI, LINGKUNGAN KERJA DAN IKLIM ORGANISASI TERHADAP MOTIVASI PEGAWAI SERTA DAMPAKNYA TERHADAP KEPUASAN KERJA. Jurnal Semarak, 2(2).

Thoha, Miftah, "Kepemimpinan Dalam Manajemen", Jakarta, Edisi Revisi, PT. Raja Grafindo, 2017.

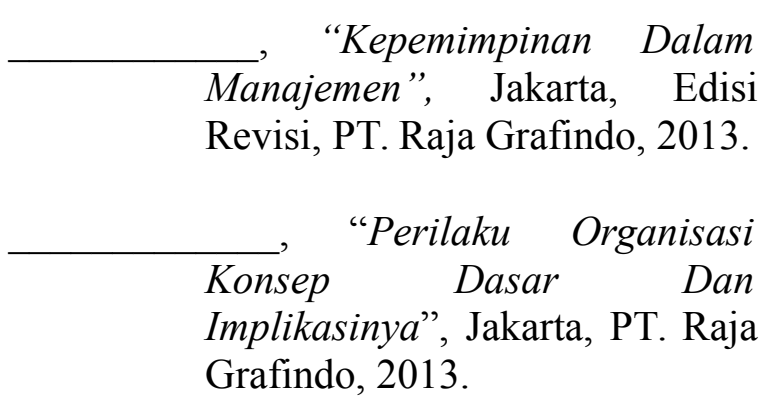




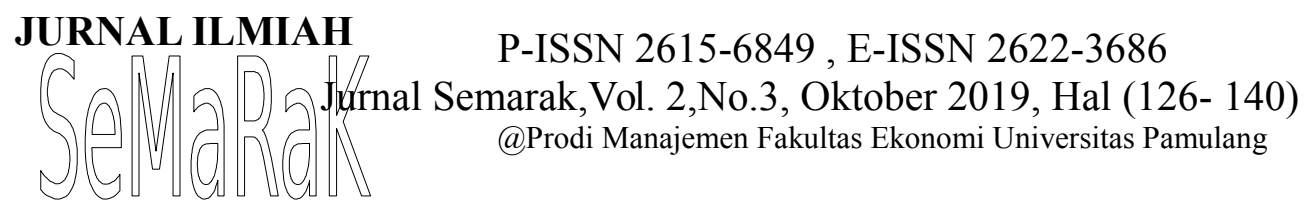

Sedarmayanti, "Manajemen Sumber Daya Manusia”, Bandung, Refika Aditama, 2013.

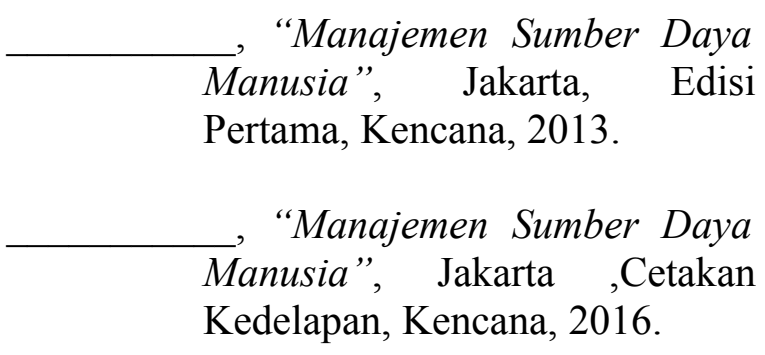

Sugiyono, "Metode Penelitian Pendidikan Pendekatan Kuantitatif, Kualitatif, dan $R \& D$, Bandung, Alfabeta, 2013.

, "Metode Penelitian Pendidikan Pendekatan Kuantitatif, Kualitatif, dan $R \& D ”$, Bandung, Alfabeta , 2014.

, "Metode Penelitian Pendidikan Pendekatan Kuantitatif, Kualitatif, dan $R \& D$, Bandung, Alfabeta, 2015.

, "Metode Penelitian Pendidikan Pendekatan Kuantitatif, Kualitatif, dan $R \& D$, Bandung, Alfabeta, 2017.

Sumarsan, Thomas, "Sistem Pengendalian Manajemen", Jakarta, Edisi 1, Indeks, 2013.

Sutrisno, Edy, "Manajemen Sumber Daya Manusia", Jakarta, Edisi Pertama, Kencana, 2014.

Widodo, Sri, "Manajemen Sumber Daya Manusia", Bandung, Manggu Media, 2015.

Sadili, Samsudin "Manajemen Sumber Daya Manusia", Bandung, Pustaka Setia, 2017.

Pasaribu, V. L. D., \& Krisnaldy, K. (2018).ANALISIS KEPUASAN JAMA'AH PADA KINERJA DEWAN KEMAKMURAN MASJID AL-HIDAYAH PERIODE TAHUN 2017. KREATIF: Jurnal Ilmiah Prodi Manajemen Universitas Pamulang, 6(4), 41-51.

Rivai, Veithzal, "Manajemen Sumber Daya Manusia untuk Perusahaan", Depok, Edisi ke 6, PT. Raja Grafindo Persada, 2014. 